\title{
Anthropogenic Disturbances Create a New Vegetation Toposequence in the Gatineau River Valley, Quebec
}

\author{
Jason Laflamme ${ }^{1, *}$, Alison D. Munson ${ }^{2}$, Pierre Grondin ${ }^{3}$ and Dominique Arseneault ${ }^{4}$ \\ 1 Direction des Inventaires Forestiers, Ministère des Forêts, de la Faune et des Parcs, 5700 4e ave. ouest, \\ Québec, QC G1H 6R1, Canada \\ 2 Centre d'étude de la Forêt, Département des Sciences du bois et de la Forêt, Université Laval, \\ 2405 rue de la Terrasse, Québec, QC G1V 0A6, Canada; alison.munson@sbf.ulaval.ca \\ 3 Direction de la Recherche Forestière, Ministère des Forêts, de la Faune et des Parcs, 2700 rue Einstein, \\ Québec, QC G1P 3W8, Canada; pierre.grondin@mffp.gouv.qc.ca \\ 4 Département de Biologie, Chimie et Géographie, Université du Québec à Rimouski, 300 allée des Ursulines, \\ Rimouski, QC G5L 3A1, Canada; dominique_arseneault@uqar.ca \\ * Correspondence: jason.laflamme@mffp.gouv.qc.ca; Tel.: +1-418-627-8669 (ext. 4279)
}

Academic Editors: Barry Brook and Jessie C. Buettel

Received: 26 August 2016; Accepted: 23 October 2016; Published: 28 October 2016

\begin{abstract}
This study measured changes in forest composition that have occurred since the preindustrial era along the toposequence of the Gatineau River Valley, Quebec, Canada $\left(5650 \mathrm{~km}^{2}\right)$, based on survey records prior to colonization (1804-1864) and recent forest inventories (1982-2006). Changes in forest cover composition over time were found to be specific to toposequence position. Maple and red oak are now more frequent on upper toposequence positions $(+26 \%,+21 \%$, respectively), whereas yellow birch, eastern hemlock, and American beech declined markedly ( $-34 \%$ to $-17 \%)$. Poplar is more frequent throughout the landscape, but particularly on mid-toposequence positions $(+40 \%)$. In contrast, white pine, frequent on all toposequence positions in the preindustrial forest, is now confined to shallow and coarse-textured soils $(-20 \%)$. The preindustrial forest types of the study area were mostly dominated by maple, yellow birch, and beech, with strong components of white pine, hemlock, and eastern white cedar, either as dominant or codominant species. In a context of ongoing anthropogenic disturbances and environmental changes, it is probably not possible to restore many of these types, except where targeted silvicultural interventions could increase the presence of certain species. The new forest types observed should be managed to ensure continuity of vital ecosystem services and functions as disturbance regimes evolve.
\end{abstract}

Keywords: preindustrial forest; forest composition; forest types; toposequence; ecological land classification; potential vegetation

\section{Introduction}

For the last several centuries, the vast forests of northeastern North America have been subjected to anthropogenic presence and associated disturbances (land clearing, selective and intensive harvest) $[1,2]$. In the eastern United States, "the great cutover" period stretched from the late 17th until the beginning of the 20th century [3], while Canadian forests began to be exploited more intensively in the early 19th century [4-6], especially for the large white pine (Pinus strobus L.) used for the construction of ships for the British navy, thus altering the forest structure and composition $[7,8]$. The new forest management regime recently adopted in Quebec is based on principles of ecosystem management, including the development of silvicultural interventions that reduce the gap between the structure and function of unmanaged (subject to natural disturbance regimes) and managed forests [9].

The forests present prior to the first large scale harvests represent reference conditions that can be reconstructed to measure composition changes that have occurred since the early 
19th century $[7,10]$. One reconstruction method involves the study of vegetation descriptions contained in land surveyor logbooks dating from settlement. Several landscape-scale studies have compared the information contained in these land survey archives to recent forest inventories in order to quantify compositional changes in the forests of northeastern America that have occurred since settlement [2,11,12]. These studies have demonstrated a decrease of coniferous in favor of deciduous species, especially early-successional shade-intolerant species such as poplar (Populus spp.) and white birch (Betula papyrifera Marsh.) [8,13,14]. Maple (Acer spp.) also increased in the northeastern United States [3,12,15-20] and eastern Canada [7,8,21-24]. White and red pine (Pinus resinosa Ait.), eastern hemlock (Tsuga canadensis (L.) Carr.) and American beech (Fagus grandifolia Ehrh.) are species which have generally experienced the greatest decline [2,17-19,23,24].

In countries with large areas of managed forests, an ecological land classification system (ELC) is frequently employed to identify ecosystem units that can be managed similarly [25-28]. One way to develop such a framework is to use the concept of toposequence, defining change of physical features and associated vegetation along slope and altitudinal gradients [26]. In Quebec, the ELC is based on homogeneous toposequence units with regards to physical attributes, forest composition, and post-disturbance recovery pathways, thus defining "potential vegetation types" (hereafter "PVT") [26]. These types are named according to the shade-tolerant species present that are favorable to their own regeneration and growth. The PVTs and associated physical features have been interpreted on 1:20,000 aerial photos by experienced photo-interpreters under the supervision of Ministère des Forêts, de la Faune et des Parcs du Québec (MFFP) and then mapped for all of Quebec's managed forests $\left(760,000 \mathrm{~km}^{2}\right)$. However, because present-day rather than historical data were used to elaborate the ELC, it may not properly capture the preindustrial forest dynamics, especially if successional pathways have been altered by anthropogenic disturbances of the 19th and 20th centuries. The goal of this study is to compare forest composition of preindustrial and present-day toposequence units (PVT) using land surveyor logbooks for the Gatineau River Valley, in southwestern Quebec. Because PVTs are currently used by forest managers, preindustrial composition information on these types may be used as a complement to ecosystem-based management. We also take the perspective of Hobbs et al. $[29,30]$ and Jackson and Hobbs [31] to consider the potential of current PVTs to be restored or managed to return to a preindustrial state. This framework was designed to guide decisions on management interventions based on the assessment of whether changes are reversible or not, on whether a new or novel ecosystem is present, and on the level of intervention and resources required for restoration.

\section{Materials and Methods}

\subsection{Study Area}

The study area $\left(5650 \mathrm{~km}^{2}\right)$ is located in southwestern Quebec (Canada), between latitudes $45^{\circ} 26^{\prime}$ and $46^{\circ} 40^{\prime} \mathrm{N}$ and longitudes $74^{\circ} 24^{\prime}$ and $76^{\circ} 31^{\prime} \mathrm{W}$ (Figure 1). It lies in a temperate deciduous forest zone, in the sugar maple-basswood bioclimatic domain, and, more specifically, in the ecological region surrounding the Gatineau River Valley [32]. The territory has one of the mildest, driest climates in the province of Quebec: the average annual temperature is 4.0 to $5.0^{\circ} \mathrm{C}$ and annual precipitation is generally less than $1000 \mathrm{~mm}$ [32]. The hydrographic network is dominated by the Gatineau River, which flows from north to south and empties into the Ottawa River. The region is characterized by a high percentage of rocky outcrops, mainly situated on steep slopes and summits. Thin to thick glacial till dominates on low to moderate slopes. The Gatineau River is surrounded primarily by glaciolacustrine deposits. Marine deposits in the lowlands at the extreme south of the territory are evidence of marine invasion during the last deglaciation [33]. Altitude varies between 95 and $500 \mathrm{~m}$, but summits rarely exceed $400 \mathrm{~m}$. As shown by the toposequence of the region, altitude has an edaphic rather than a climatic effect, since more mesophilous species are present principally on higher altitudes. 


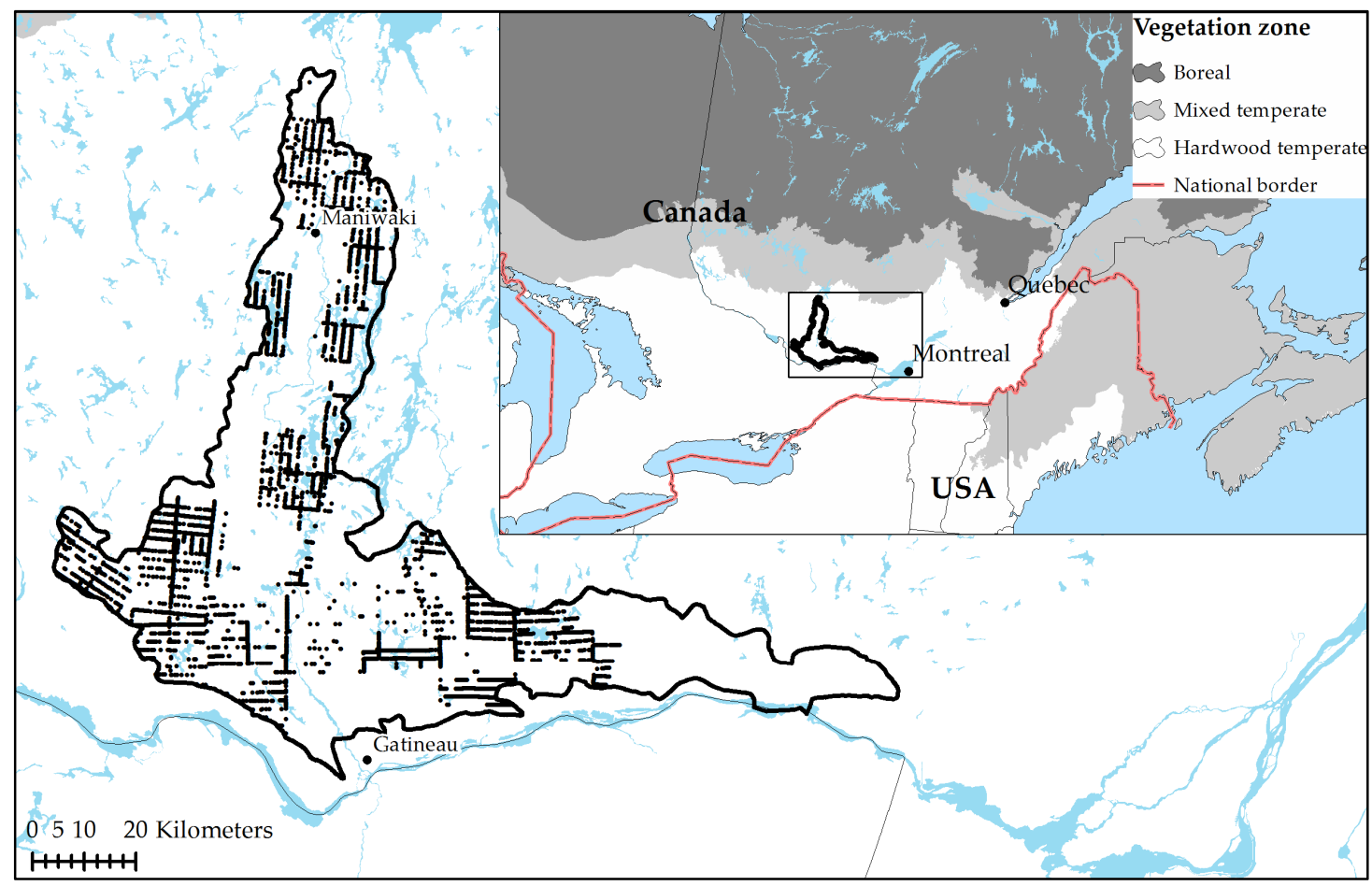

Figure 1. Location of the Gatineau River Valley ecological region [32] and the preindustrial land surveys observations (black dots). Vegetation zones are delineated according to Saucier et al. [26] (Quebec) and Brandt [34] (outside Quebec).

Indeed, on the upper portion of the toposequence, deciduous forest stands, particularly shade-tolerant sugar maple (Acer saccharum Marsh.) stands, are abundant (Table 1, Figure 2). On low summits and tops of slopes with thin deposits, sugar maple accompanies red oak (Quercus rubra L.), forming the Quercus rubra (FC1) and Acer saccharum-Quercus rubra (FE6) PVTs. On richer sites where deposits are deeper, sugar maple is accompanied by different shade-tolerant deciduous species, including basswood (Tilia americana L.) and American beech, forming the Acer saccharum-Tilia americana PVT (FE2). While this matrix is dominated by sugar maple, there are also patches of hemlock, which are generally small (PVT RT1). Lower on the slope, on the middle of the toposequence, sugar maple is gradually replaced by balsam fir (Abies balsamea (L.) Mill.), yellow birch (Betula alleghaniensis Britton), and trembling aspen (Populus tremuloides Michx.), forming the mixed Betula alleghaniensis-Abies balsamea-Acer saccharum PVT (MJ1). Stands of white pine and red pine (PVT RP1) also constitute an important element on this portion of the toposequence; they are mainly present on thin or coarse-textured deposits. Finally, on the lower portion of the toposequence, which generally drains more slowly due to flat slopes, diverse assemblages of mixed and coniferous covers are present. Species such as balsam fir (Abies balsamea-Thuja occidentalis PVT (RS1)), black ash (Fraxinus nigra Marsh.) (Fraxinus nigra-Abies balsamea PVT (MF1)), and eastern white cedar (Thuja occidentalis L.) ((Thuja occidentalis-Abies balsamea PVT (RC3)) are each dominant, depending on site characteristics. 
Table 1. Description of the ten potential vegetation types (PVTs) of Quebec's ecological land classification (ELC) in the study area [35]. The first character of the PVT code refers to the cover type (in French): (F) "Feuillu": deciduous, (M) "Mixte": mixed, and (R) "Résineux": coniferous. The second character refers to the PVT dominant species (in French or Latin): (C) "Chêne rouge": red oak, (E) "Érable à sucre": sugar maple, $(\mathrm{T})$ "Tsuga canadensis": hemlock, (J) "Bouleau jaune": yellow birch, $(\mathrm{P})$ "Pin blanc ou rouge": white or red pine, (B) "Épinette blanche": white spruce, (S) "Sapin baumier": balsam fir, (F) "Frêne noir": black ash, (C) "Cèdre": eastern white cedar. The third character is a numerical sequence to distinguish PVTs which have the same cover type and the same dominant species.

\begin{tabular}{|c|c|c|c|c|c|}
\hline $\begin{array}{l}\text { Slope } \\
\text { Position }\end{array}$ & Code & Potential Vegetation Types (PVT) & $\begin{array}{c}\text { Mean } \\
\text { Elevation }\end{array}$ & Mean Slope & Area \\
\hline & & & (m) & $(\%)$ & $(\%)$ \\
\hline \multirow{4}{*}{ Upper } & FC1 & Quercus rubra & $273 \pm 68$ & $21 \pm 10$ & 6.1 \\
\hline & FE6 & Acer saccharum-Quercus rubra & $247 \pm 57$ & $17 \pm 8$ & 15.7 \\
\hline & FE2 & Acer saccharum-Tilia americana & $230 \pm 57$ & $13 \pm 7$ & 32.1 \\
\hline & RT1 & Tsuga canadensis & $239 \pm 59$ & $21 \pm 11$ & 2.6 \\
\hline \multirow{3}{*}{ Middle } & MJ1 & Betula alleghaniensis-Abies balsamea-Acer saccharum & $199 \pm 46$ & $8 \pm 6$ & 23.9 \\
\hline & RP1 & Pinus strobus-Pinus resinosa & $199 \pm 41$ & $13 \pm 10$ & 4.4 \\
\hline & RB1 & Picea glauca-Thuja occidentalis (old fields) & $182 \pm 29$ & $6 \pm 4$ & 5.5 \\
\hline \multirow{4}{*}{ Lower } & RS1 & Abies balsamea-Thuja occidentalis & $187 \pm 30$ & $7 \pm 6$ & 3.9 \\
\hline & MF1 & Fraxinus nigra-Abies balsamea & $185 \pm 34$ & $4 \pm 3$ & 2.2 \\
\hline & $\mathrm{RC} 3$ & Thuja occidentalis-Abies balsamea & $195 \pm 28$ & $3 \pm 3$ & 2.5 \\
\hline & & Other PVTs & & & 1.2 \\
\hline
\end{tabular}

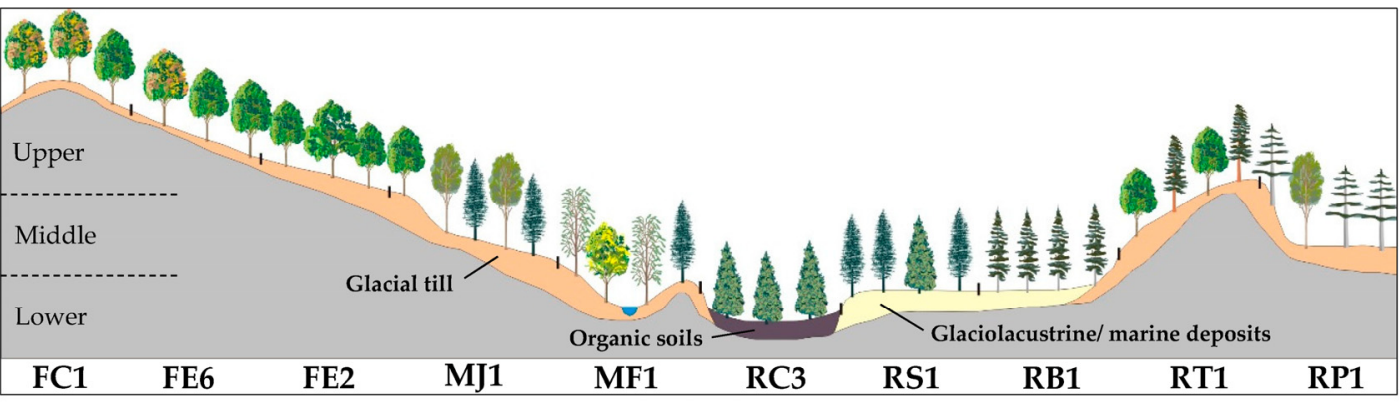

Figure 2. Present-day toposequence of the study area. Potential vegetation type (PVT) codes are presented in Table 1.

\subsection{Preindustrial Forest Composition}

The data source used to characterize preindustrial vegetation consists of surveyors' observation notebooks filed in Le Greffe de l'arpenteur général du Québec [36]. The surveyors described elements observed along the boundary lines drawn in forested areas for the purpose of staking out lots. Specifically, they compiled lists of tree species (taxa) present in the forest, noting the exact location point of each observation. To do this, they noted the distance travelled in chains (1 chain = $20.1 \mathrm{~m})$ and the azimut from the starting point of a known location. Fifty-one (51) surveyors' notebooks dating from 1804 to 1905 were available for characterizing the preindustrial landscape of the study area. However, since the number of observations associated with human disturbances (e.g., "logged", "cleared land", etc.) increased drastically as of the 1870s, information from notebooks dating from the late 1860s and on was not included. Thus, our study focused on the contents of thirty-two (32) notebooks dating from 1804 to 1864 ; however, the majority $(84 \%)$ of the vegetation-related observations were made between 1841 and 1864.

Tabulation, data entry, and georeferencing of the surveyors' observations followed the method used by Dupuis et al. [7]. The observations noted in the notebooks were retranscribed into a numerical database. These observations were then georeferenced in a geographic information system using digital property map data of lot and district boundaries. The position of observations made during 
surveying was corrected by comparing the distances between waterways on property maps and those measured by the surveyors. Finally, these observations were superimposed on the map of PVTs.

A total of 4259 vegetation-related observations of preindustrial forest composition were retained for this study (Figure 1). These observations corresponded to taxa lists (e.g., "maple, beech, and birch", $59 \%$ ), cover type (e.g., "mixedwood", 31\%), or a combination of the two (e.g., "pine and hardwood", $9 \%$ ). Surveyors did not generally distinguish between different species of maple, poplar, oak, elm, ash, pine, or spruce. However, we assumed that the majority of mentions of "oak" referred to red oak, since it is the only oak species present in the region today; "pine" referred mostly to white pine or red pine, since jack pine (Pinus banksiana Lamb.) is rare in the study area. A few regional expressions or popular names were used by the surveyors; they were associated to a species or genus following Fournier [37,38]. For example, "plaine" $(n=1)$ and "soft maple" $(n=9)$ were associated to red maple and consequently to maple, "épinette rouge" $(n=3)$ to tamarack, and "black birch" $(n=16)$ to yellow birch. Taxa were apparently noted from the most important to the least important, as suggested by many authors [39-41] and statistically demonstrated by Terrail et al. [42]. Position on the list was transformed into a measure of abundance following the broken-stick model [43]. This distribution model assigns a relative abundance to each taxon as a function of its position and of the number of taxa in a list.

\subsection{Current Forest Composition}

Forest survey plots of the MFFP were used to describe current vegetation [44]. These circular plots $\left(\mathrm{r}=11.28 \mathrm{~m} ; 400 \mathrm{~m}^{2}\right)$ measured by forest technicians are used to estimate the wood volume available for the forest industry of different forest types. The diameter at breast height (DBH) of all stems of tree species greater than $9.1 \mathrm{~cm}$ was measured in each plot, and then transformed into basal area per hectare per species $\left(\mathrm{m}^{2} / \mathrm{ha}\right)$. Species identified at the genus level by surveyors (maple, poplar, oak, elm, ash, pine, and spruce) were combined in the same taxon for each plot, by summing their basal area. Also, because there are generally more taxa present in recent survey plots compared to preindustrial observations, we removed those less than $10 \%$ of the total plot basal area. Subsequently, a list was created ordering the taxa from the most important to the least important in terms of basal area for each plot. The taxa list was retransformed into a measure of abundance following the broken-stick distribution model, so that data would be similar to that of the land survey records. Basal area is considered to be a good measure of the importance of taxa in a stand, and thus an adequate comparative measurement, since it takes into account both stem density and diameter [42]. Finally, the plots were superimposed on the map of PVTs. For the study area, a total of 4574 plots, measured between 1982 and 2006, were used for the analyses.

\subsection{Evolution of the Forest Composition of Potential Vegetation Types}

In order to evaluate the changes in forest composition that took place from the preindustrial period to today, three different levels of analysis were retained. The first level aims to characterize the cover type, defined as a function of the percentage occupied in each preindustrial observation and each recent survey plot by coniferous species (coniferous: $>75 \%$, mixed: between $25 \%$ and $75 \%$, deciduous: $<25 \%$ ). The average frequency of each cover type was then calculated for the ten PVTs, and the two periods were compared.

The second level evaluates the prevalence of each taxon (i.e., the percentage of sites on which a taxon is present). The prevalence was calculated for the ten PVTs, for each period. In order to evaluate whether changes between the two periods were significant, a logistical regression (logit) of the genmod procedure in SAS 9.3 software was applied on these metrics. A Bonferroni correction was applied to limit type I errors. A correspondence analysis (CA) was performed on the abundance matrices in order to visualize the evolution of the forest composition of each PVT between the two periods. This was achieved by combining the matrices of taxa of the two periods and by using the vegan package [45] of the software R (version 2.12.0) [46]. The centroid of sites having the same PVT was calculated 
and placed within the ordination biplot for each period. A succession vector was then drawn on the ordination biplot.

Finally, the third level of analysis was designed to calculate, for each period, the main forest types, namely groups of sites with similar tree species composition. Each abundance matrix of taxa was transformed into a Bray-Curtis distance matrix, which was submitted to Ward's hierarchical clustering [47]. The number of groups was chosen to reveal significant distinctions among them while avoiding the confusion that could arise from a too large number [48]. These analyses were performed using the stats and vegan packages [45] of the software R (version 2.12.0) [46].

\section{Results}

\subsection{Cover Type}

In the preindustrial period, the forests of the Gatineau River Valley were mainly deciduous (45\% of observations) (Figure 3, horizontal dotted lines). Mixed and coniferous covers were relatively important, however, occupying $30 \%$ and $25 \%$ of observations, respectively. Today, deciduous (48\%) and mixed $(38 \%)$ covers are still more frequent, whereas coniferous covers have become rare $(15 \%)$.

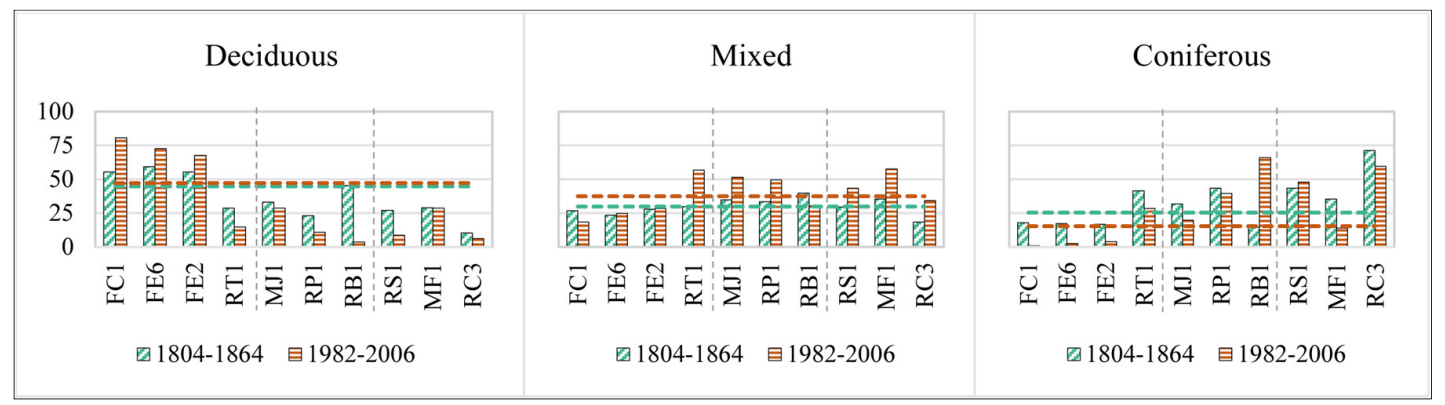

Figure 3. Proportion (\%) of cover types for the preindustrial and present-day periods. Horizontal dotted lines correspond to the average for the entire study area. Potential vegetation types (PVTs) are grouped according to their position on the toposequence (upper, middle, lower); PVT codes are presented in Table 1.

The upper portion of the toposequence is more deciduous and less coniferous today than in the earlier time period (Figure 3). For example, for the Quercus rubra PVT (FC1), deciduous cover has strongly increased $(+25 \%)$ while coniferous cover has decreased $(-17 \%)$. On the middle and lower portions of the toposequence, the mixed cover type has increased the most, an increase closely linked to the decrease in coniferous cover. Only on the old field Picea glauca-Thuja occidentalis PVT (RB1) has coniferous cover shown an increase.

\subsection{Tree Species}

Yellow birch, maple, and pine were the three taxa most frequently mentioned by surveyors ( $39 \%$ to $33 \%$ ), followed by hemlock, cedar, beech, balsam fir, and spruce ( $26 \%$ to $18 \%$ ) (Figure 4 , horizontal dotted lines). Comparison of the preindustrial taxon prevalence with recent inventories shows that yellow birch, pine, hemlock, and cedar are the five taxa that have experienced the greatest decline $(-30 \%$ to $-10 \%)$. Their decline has mainly benefited poplar, maple, red oak, and balsam fir $(+30 \%$ to $+13 \%)$.

On the upper toposequence, maple, poplar, and red oak have shown the most dramatic increase $(+26 \%$ to $+21 \%)$ (Figure 4). During the preindustrial period, this portion of the toposequence was more often dominated by yellow birch, hemlock, pine, and beech $(-34 \%$ to $-17 \%)$. The ordination of the correspondence analysis shows that PVTs dominated by maple (FC1, FE6, and FE2) had a similar composition during the preindustrial period, hence their proximity on the ordination, and that they 
have all evolved in the same direction, particularly due to the increase of maple and red oak (Figure 5). According to the ordination, the current forest composition of the Tsuga canadensis PVT (RT1) seems to increasingly resemble the preindustrial pattern of these three other PVTs situated at the upper portion of the toposequence.
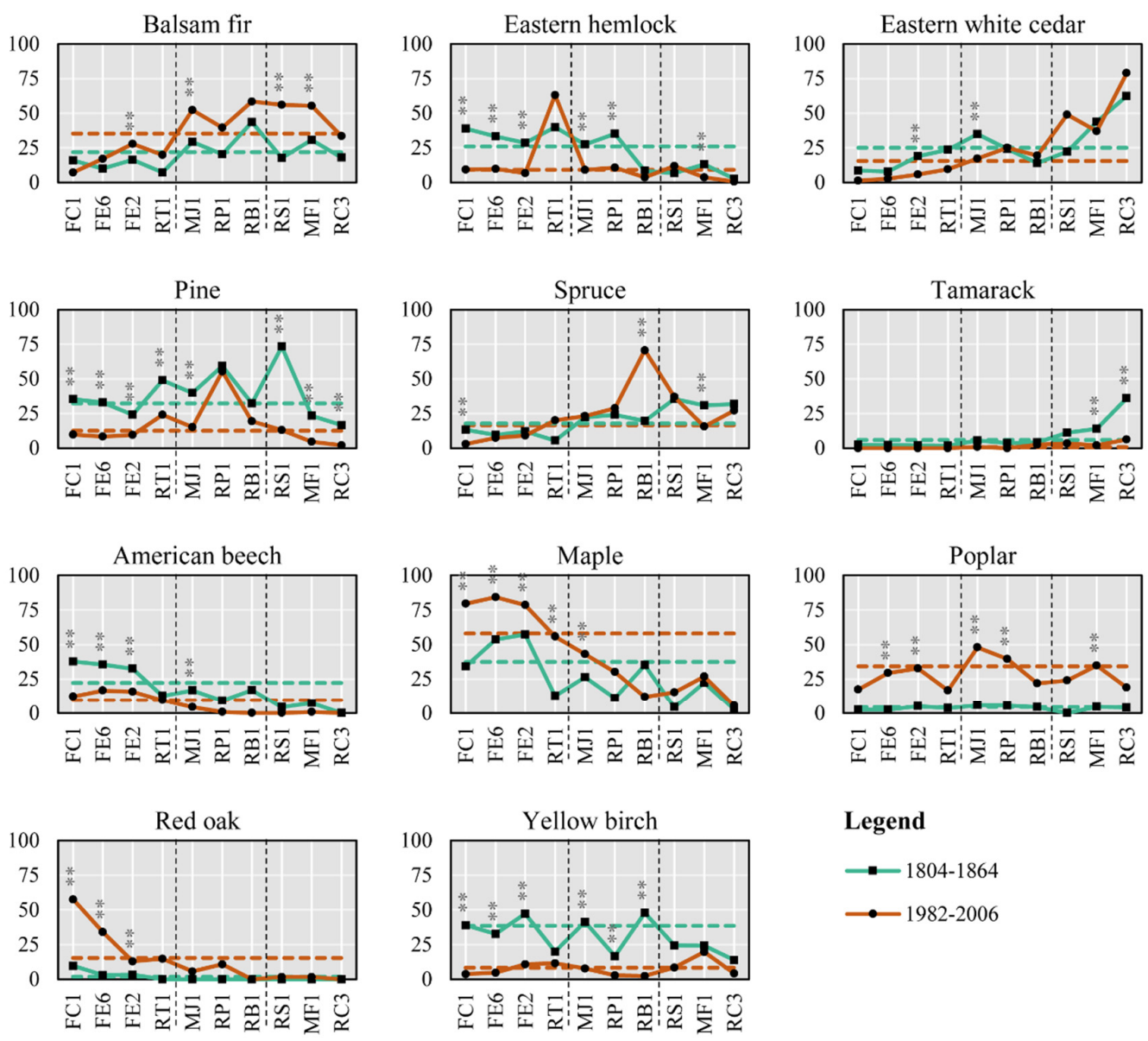

\section{Legend}

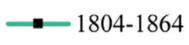

$\longrightarrow 1982-2006$

Figure 4. Prevalence (\%) of the six coniferous and five deciduous main taxa for the ten potential vegetation types (PVTs) for the preindustrial and current eras. Asterisks indicate significant changes at $\alpha=0.01{ }^{* *}$. Horizontal dotted lines correspond to the average prevalence for the entire study area. PVTs are grouped according to their position on the toposequence (upper, middle, lower); PVT codes are presented in Table 1. Less frequent taxa (less than $5 \%$ in preindustrial and present-day eras) are not presented.

On the middle of the toposequence, poplar shows a strong increase $(+40 \%)$, as does fir $(+21 \%)$, whereas yellow birch, pine, hemlock, and cedar show a strong decrease $(-33 \%$ to $-14 \%)$ (Figure 4). The vectors of the Betula alleghaniensis-Abies balsamea-Acer saccharum PVT (MJ1) and the Pinus strobus-Pinus resinosa PVT (RP1) clearly show that these PVTs are currently more often dominated by poplar (Figure 5). Furthermore, the current position of the RP1 succession vector ends at the preindustrial position of MJ1, which confirms that the latter was originally well-stocked with pine. On sites that were cleared for agriculture after preindustrial surveying was completed, but that have reforested naturally during the period extending up to the present time (RB1), spruce has increased sharply $(+51 \%)$.

On the lower portion of the toposequence, changes in composition are similar to those that occurred on the middle portion: taxa that have shown the greatest increase are balsam fir $(+26 \%)$ and poplar (+24\%). Also, pine has decreased sharply in the Abies balsamea-Thuja occidentalis PVT (RS1). Pine was the most common taxon in the preindustrial period (73\%), but is rare today (13\%). Tamarack, 
which was relatively frequent in the two PVTs situated on poor drainage sites (MF1 and RC3), has virtually disappeared.

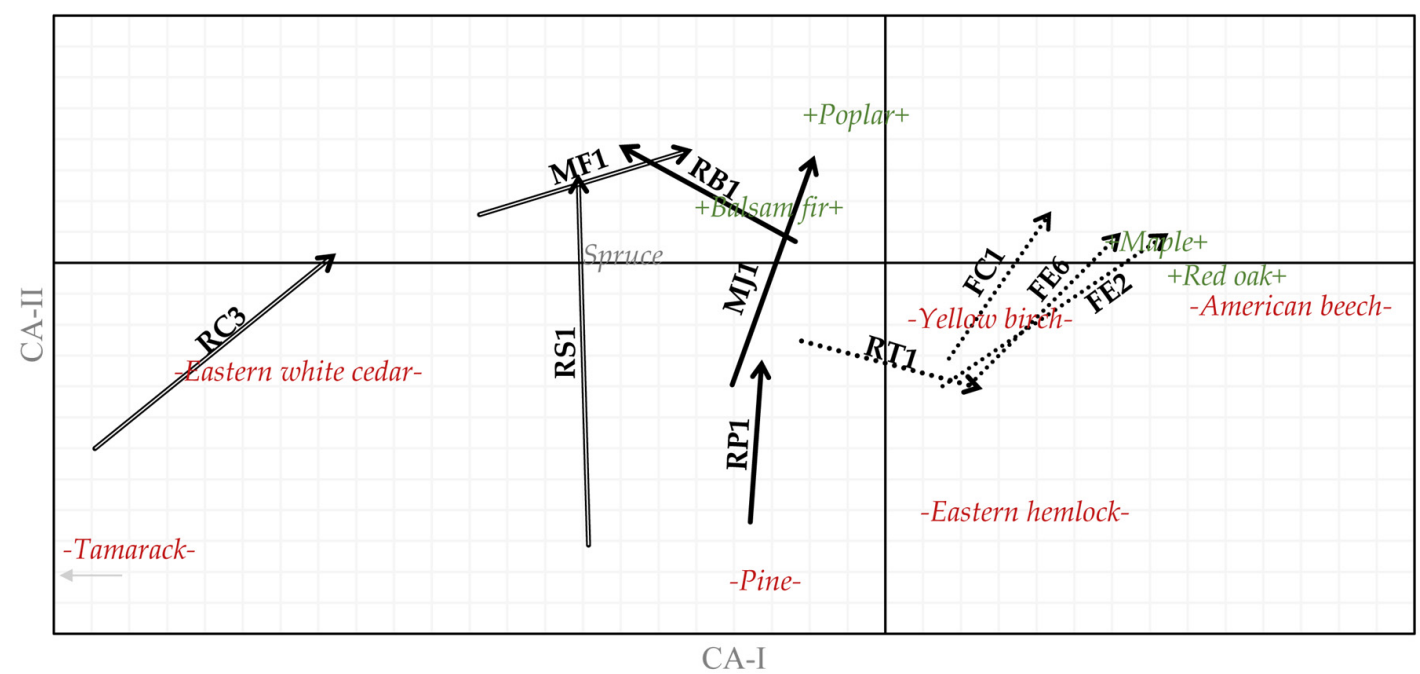

Figure 5. Evolution of the forest composition of potential vegetation types (PVTs) on the ordination formed by the two first axis of the correspondence analysis (CA). The starting point for each vector corresponds to the centroids of preindustrial sites (1804-1864), and the end point to present-day sites (1982-2006). Taxa names that have experienced a generalized increase across the landscape are in +green+, those that have decreased in -red-, and those that have shown no significant change are shown in black. The first axis represents the increase of maple (right direction), whereas the second axis represents the increase of poplar and the decrease of pine (upward direction). PVTs are ranked according to their location on the toposequence: upper (dotted lines), middle (full lines), and lower (double lines). PVT codes are presented in Table 1.

\subsection{Forest Types}

The two dendrograms obtained by Ward's hierarchical clustering were divided to obtain ten $(n=10)$ preindustrial forest types and nine $(n=9)$ present-day forest types (Table 2$)$. The "Pine" type $(18 \%)$ was the most frequent during the preindustrial period, followed by the "Maple-Yellow birch-Beech", "Cedar", "Hemlock-Pine-Yellow birch" and "Beech-Maple" types (15\% to 11\%). The "Maple" type dominates currently (30\%), whereas "Poplar-Maple-Balsam fir" and "Balsam fir" are common (16\% and $11 \%)$.

On the upper portion of the toposequence, the deciduous forest types dominated by maple and beech were common, much as were those dominated by hemlock and pine. Today, maple stands largely dominate this portion of the landscape (44\%). On the middle of the toposequence, the "Pine", "Cedar", and "Hemlock-Pine-Yellow birch" types occupied the majority of the area, whereas today "Poplar-Maple-Balsam fir", "Balsam fir", and "Maple" dominate. On the lower portion of the toposequence, the "Cedar" type was and remains dominant. Pine stands have virtually disappeared there today.

New forest types are now part of the Gatineau River Valley landscape. This is the case notably for "Poplar-Maple-Balsam fir", which is common throughout the landscape, and "Red oak-Maple", now an important element at the top of the toposequence. Inversely, other forest types have disappeared: for example, those dominated by yellow birch and by tamarack. The internal composition of certain forest types has shifted: this is the case for the "Maple" type, in which maple dominates strongly at the present time; yellow birch and beech were important companion species in the preindustrial period (Tables A1 and A2). As well, hemlock, which is now primarily associated with maple, was in the past commonly accompanied by pine and yellow birch. 
Table 2. Relative frequency (\%) of the ten preindustrial (A) and the nine present-day (B) forest types obtained by Ward's hierarchical clustering as a function of their position on the toposequence (upper, middle, lower). Forest type number (\#) corresponds to position on the dendrogram.

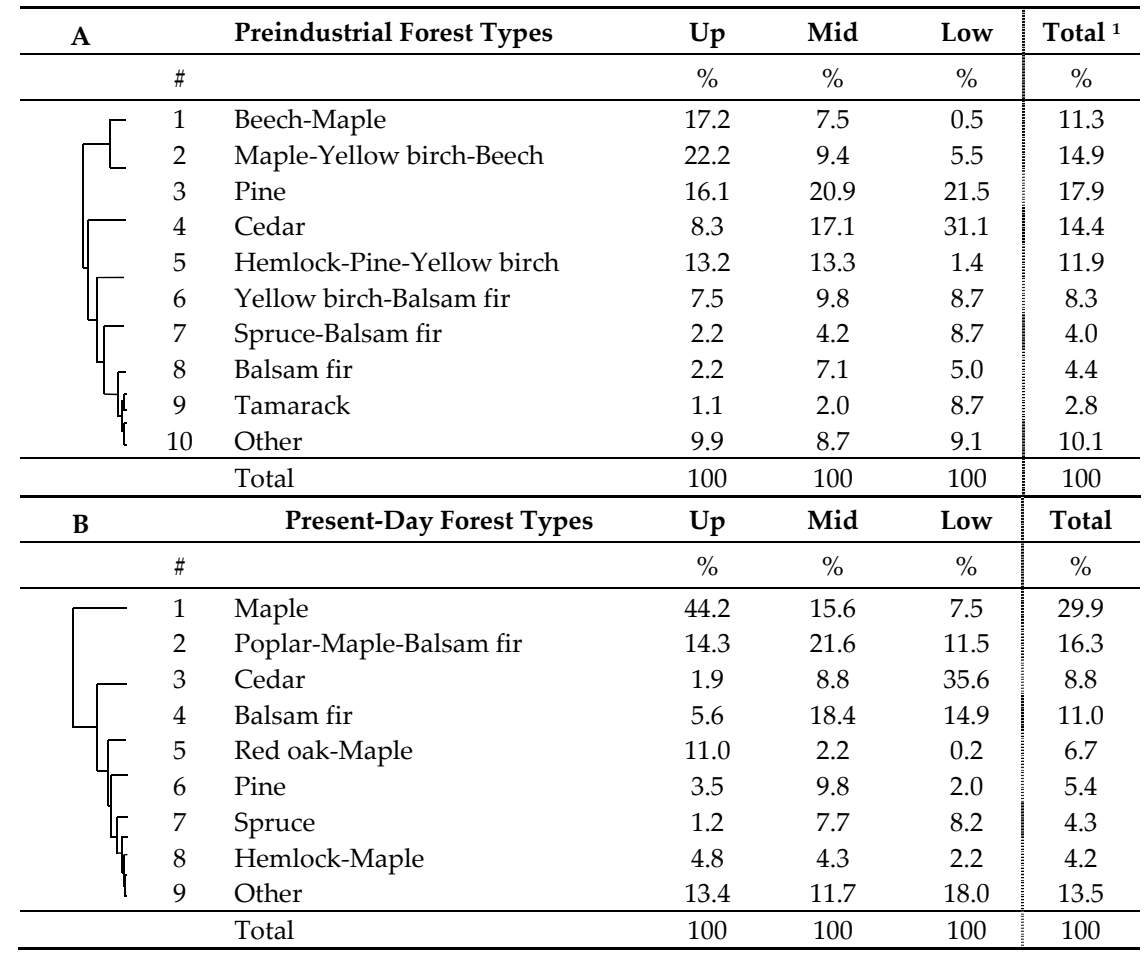

${ }^{1}$ Total includes present-day non-forested areas.

\section{Discussion}

Forest composition in the Gatineau River Valley has changed significantly since the preindustrial era. Our hypothesis is that major anthropogenic disturbances, such as selective harvesting of specific species, chronic silvicultural practices such as single-tree selection, human-caused fires, agriculture, and exotic pathogens are all important factors that contributed to the present state of the forest in this region. These changes in tree species composition and forest types have diverse consequences for setting restoration or management targets [30]. This new knowledge should inform ecosystem-based management in the hardwood temperate forest as well as Quebec's ELC.

\subsection{Loss of Targeted Species}

\subsubsection{Pine: The Great Decline}

The decrease in pine is evident throughout the entire toposequence. The "Pine" forest type, which was the most common during the preindustrial period, is rare today and confined to thin or coarse-textured deposits. Pine has decreased similarly in many other regions of northeastern North America [5,8,13,14,17-19,24,39,49-54]. Several factors may be responsible for the decrease in pine. First, selective harvesting of the highest quality stems, from the beginning of the 19th century and on, removed valuable seed resources from forests, thereby decreasing the possibility of natural reseeding on sites with good potential for germination [16]. Selective harvesting often took place in winter, thus not disturbing the organic or mineral soil layers. Consequently, this type of harvesting may not favor pine regeneration since seeds must fall on mineral soil in order to germinate [55]. As well, large fires that occurred at the end of the 19th and beginning of the 20th centuries could have destroyed the seedlings and saplings that remained untouched by logging [52]. Paradoxically, the systematic suppression of fire since the 1920s lowered the chances of pine regeneration: on the most fertile sites, a fire of moderate intensity can be required to burn forest litter and ensure seed 
germination [5]. Consequently, the decrease in burned area certainly contributed to the decrease in pine $[5,13,18,56]$. Finally, white pine blister rust (Cronartium ribicola J. C. Fisch.) is another factor that could be considered more recently.

The scarcity of pine stands and patches is probably one of the most important management issues today in temperate deciduous forests [57]. Considering the marked decline of pine in most topographical positions, it will not be feasible to restore this species to its former landscape dominance (i.e., changes are not reversible (framework of Hobbs et al., 2014) [30]). However, depending on objectives and resources, the presence of pine could be increased in many patches by active management such as the creation of large gaps [58] and prescribed burns [59]. To improve the distribution of the Pinus strobus-Pinus resinosa (RP1) PVT in Quebec's ELC, modelling of the preindustrial distribution of pine might be considered to determine more precisely the sites where this taxon was previously found [52].

\subsubsection{Hemlock Has Been Replaced by Maple}

Eastern hemlock has decreased substantially on the upper and middle portions of the toposequence. The forest type dominated by the species is today about three times less represented than during the preindustrial period. As with pine, a decrease has also been observed across the United States $[2,17-19,60]$ and eastern Canada $[4,21,22,24,61]$.

Hemlock was also a species targeted for logging; however, as shown by dendrochronological dating of submerged logs [6] and wood sales reported in old notary deeds [4], it was harvested in later years, probably because hemlock products had other uses than pine, including the use of its bark in the leather-tanning process and its wood for railway ties. Selective harvesting would have thus contributed to the species' decrease directly as well as indirectly, since the removal of hemlock from mixed stands can lead to its replacement by sugar maple [21,62]. While hemlock is today associated with maple, during the period in which this landscape was originally surveyed, it was associated with white pine. A recent study showed that this type of association dominated by long-lived trees that have self-pruning stems and a thick bark was able to evolve following a regime of recurrent surface fires [63].

The important decrease of hemlock suggests that the Tsuga canadensis (RT1) PVT is underestimated in Quebec's ELC in the study area. Many sites formerly occupied by hemlock stands reflect a new successional dynamic today, represented by PVTs dominated by sugar maple (FC1, FE6, and FE2). As for pine, this change seems irreversible, and a return to the preindustrial state is probably impossible without a robust ecological restoration program.

\subsection{Modification of Internal Stand Composition}

Loss of the Two Main Companion Tree Species to Maple

Maple stands composed of sugar maple, yellow birch, and beech were one of the most common forest types in the region's forest landscapes during the preindustrial period. It has been suggested that this type represented one of the stable states of the forest on mesic sites of the St. Lawrence Lowlands [64]. This is supported by the composition of one of the last remaining examples representative of the primitive forests of southwestern Quebec (ecological reserve Forêt-la-Blanche) [65]. According to wood sales reported in old notary deeds from the 19th century, the most important change in maple stands since European colonization is a decline in the abundance of beech and yellow birch, combined with an increase of sugar maple [22]. The forest types dominated by these two species, "Beech-Maple" and "Yellow birch-Balsam fir", have now disappeared from the study area. Today, maple (primarily sugar maple) constitutes the dominant element of the upper portion of the toposequence.

The great ecological versatility of sugar maple and its phenotypic plasticity may have allowed the species to take advantage of a variety of disturbances as well as the overall conditions generated 
by current landscapes [66]. Sugar maple can be considered a generalist or trans-successional species, since it can achieve a level of abundance at both the beginning and the end of a successional sequence [66,67]. Its increase in abundance would have been achieved to the detriment of yellow birch, a species targeted for logging in the middle of the 20th century and one that regenerates primarily on woody debris, which are less common in managed forests $[68,69]$. The decline of beech, which was one of the most important components of preindustrial forests in the American northeast [2,15], could also be attributed to specific recurrent silvicultural practices and, more recently, to beech bark disease $[3,70]$.

The Acer saccharum-Tilia americana PVT (FE2), as proposed by Quebec's ELC and by some authors who defined a typology of maple stands [71], seems to be closer to the preindustrial "Maple-Yellow birch-Beech" forest type. The loss of these two companion species has a certain impact on silvicultural treatments that should be applied on this PVT, if we want to return more closely to the preindustrial state. In this case, partial cuts, which are actually prescribed in this PVT, should be adapted to favor companion species. For example, this would include leaving woody debris on the ground and increasing light availability by creating larger gaps when harvesting to favor yellow birch [72]. A return to a historical state would seem feasible with known and modest management interventions [31].

\subsection{Novel Ecosystems}

\subsubsection{Old Fields}

Old fields that have reforested naturally form the only PVT (RB1) that is now more coniferous than during the preindustrial period, due to white spruce being particularly well adapted to colonizing these sites. This phenomenon has been observed in the Maritime Provinces, where the species is sometimes referred to as "field spruce" [25,73]. In contrast, in certain areas of New England, white pine has regenerated on abandoned agricultural land $[2,12]$. In the study area, the heavy harvest of white pine probably diminished the species' chances of colonizing these sites. In any event, the RB1 PVT has diverged so substantially from its preindustrial state that it can be considered as a novel ecosystem of anthropic origin [29]. Because conventional restoration cannot be applied to this PVT, different management options can be considered. For example, planting rapid-growth trees could be an interesting option to consider for wood production.

\subsubsection{Red Oak Stands}

While red oak stands were virtually absent from natural landscapes and the species was rare in all other preindustrial forest types, today it forms pure stands that are well represented on the region's low summits with thin soils. As several studies have shown, red oak has increased in many regions of northeastern North America $[13,19,20,24,49,74]$. The species is not typically dominant in late successional forests, and forms stands that evolve according to a cyclical dynamic maintained by fires [75]. The beginning of the 20th century was a propitious period for forest fires, in part due to colonization $[7,76,77]$. The presence and current abundance of red oak therefore can be linked to anthropic fire regimes [78]. Furthermore, the two taxa targeted by logging during the 19th century, pine and hemlock, were the most common in the Quercus rubra PVT (FC1); their harvesting could thus have contributed to the increase of red oak. We conclude that most red oak stands classified today as FC1 may in fact correspond to a successional stage towards other PVTs. Because this PVT was not present in the preindustrial state, it can be considered as a novel ecosystem with potential to be managed for a range of ecosystem services, including fibre [30].

\subsubsection{Early Successional Stands: The Case of Poplar}

While poplar was virtually absent from the preindustrial forests of the Gatineau River Valley, today it constitutes a major component. This major increase occurred across the entire landscape, but particularly on the middle of the toposequence. This early successional taxon is highly 
shade-intolerant, and is thus favored by frequent, intense disturbances. Poplars produce a large quantity of seeds that are wind-dispersed, and have a highly efficient mode of reproduction by stump sprouts and root suckers [79]. The increase in poplar is a generalized phenomenon in northeastern North America, but particularly in Quebec, where its abundance seems strongly correlated with fires [80], including bush fires set by settlers while clearing the land [76]. Again, these represent novel ecosystems that can be oriented in different trajectories depending on current management goals and targeted services.

\section{Conclusions}

Our findings enrich our knowledge of the past and current state of the forest of the Gatineau River Valley. During the preindustrial period, the forest resembled the maple-yellow birch-beech forest described in retrospective studies of the northeastern US landscape. White pine and eastern hemlock were almost equally common, as either canopy dominants or sub-dominants. The main forest types of the preindustrial forest are no longer prevalent in the landscape we studied. Therefore, if Quebec's ELC had been developed using preindustrial rather than modern data, different potential vegetation types would have been created.

According to the level of effort required to restore these new forest types [31], there are a range of possible options available to managers. The restoration of certain types among which there has been less dramatic change could be achieved through targeted silvicultural interventions to increase the presence of certain species that that have been rarefied, such as in the case of maple stands. In other cases, it is questionable whether previous landscapes can in fact be restored, such as widespread dominance of pine and hemlock, and other late successional species. In the context of global environmental change, as well as invasions by exotic pests and pathogens, restoration could require immense resources. The new forest types described by the potential vegetation types represent the current state of our forests, and the principal objectives of management in this context may be to ensure continuity of functions and essential services (biodiversity, fibre, recreation, culture) of ecosystems under changing disturbance regimes.

Acknowledgments: We are most grateful to Sébastien Dupuis and Marie Leroyer, who constructed the land survey records database. We extend our thanks to Jocelyn Gosselin (Direction des inventaires forestiers, MFFP) who provided the recent forest inventory database. Two reviewers made constructive comments on the previous version of this manuscript. This study was funded by an NSERC Strategic grant.

Author Contributions: J.L., A.D.M., P.G., and D.A. conceived and designed the research; J.L. performed the experiments and analyzed the data; P.G. contributed to analysis; J.L. wrote the paper with the help of all the authors.

Conflicts of Interest: The authors declare no conflict of interest.

\section{Appendix A}

Table A1. Relative abundance of taxa for groups $(n=10)$ from the preindustrial period, obtained by Ward's hierarchical clustering.

\begin{tabular}{ccccccccccc}
\hline Preindustrial Forest Type \# & $\mathbf{1}$ & $\mathbf{2}$ & $\mathbf{3}$ & $\mathbf{4}$ & $\mathbf{5}$ & $\mathbf{6}$ & $\mathbf{7}$ & $\mathbf{8}$ & $\mathbf{9}$ & $\mathbf{1 0}$ \\
\hline $\boldsymbol{n}$ & 282 & 373 & 447 & 360 & 298 & 207 & 101 & 110 & 70 & 252 \\
Acer spp. & 21.0 & 63.3 & 3.1 & 0.8 & 3.0 & 8.5 & 3.8 & 2.1 & 0.0 & 6.9 \\
Betula alleghaniensis & 7.9 & 11.9 & 3.6 & 2.7 & 7.4 & 59.8 & 5.1 & 9.5 & 1.5 & 5.9 \\
Betula papyrifera & 0.4 & 0.1 & 0.5 & 0.3 & 1.0 & 0.0 & 0.3 & 0.8 & 0.6 & 8.4 \\
Fagus grandifolia & 63.8 & 10.0 & 0.6 & 0.1 & 2.8 & 2.7 & 0.4 & 2.2 & 0.0 & 0.7 \\
Fraxinus spp. & 0.0 & 0.3 & 0.3 & 2.2 & 0.1 & 0.5 & 1.0 & 0.8 & 0.3 & 29.6 \\
Ostrya virginiana & 0.6 & 0.5 & 0.1 & 0.0 & 0.0 & 0.4 & 0.0 & 0.1 & 0.0 & 1.5 \\
Populus spp. & 0.0 & 0.5 & 0.8 & 0.1 & 0.0 & 1.1 & 0.0 & 1.6 & 0.2 & 10.7 \\
Quercus spp. & 0.1 & 0.5 & 0.1 & 0.0 & 0.2 & 0.2 & 0.0 & 0.1 & 0.0 & 5.4 \\
Tilia americana & 0.7 & 4.4 & 0.2 & 0.2 & 0.1 & 2.0 & 0.0 & 0.2 & 0.0 & 4.3 \\
\hline
\end{tabular}


Table A1. Cont.

\begin{tabular}{ccccccccccc}
\hline Preindustrial Forest Type \# & $\mathbf{1}$ & $\mathbf{2}$ & $\mathbf{3}$ & $\mathbf{4}$ & $\mathbf{5}$ & $\mathbf{6}$ & $\mathbf{7}$ & $\mathbf{8}$ & $\mathbf{9}$ & $\mathbf{1 0}$ \\
\hline Ulmus spp. & 0.1 & 0.9 & 0.1 & 0.3 & 0.0 & 0.9 & 0.2 & 0.6 & 0.0 & 12.8 \\
Abies balsamea & 0.4 & 1.8 & 2.4 & 3.6 & 1.7 & 9.4 & 7.3 & 63.5 & 1.2 & 3.0 \\
Larix laricina & 0.0 & 0.0 & 0.4 & 2.1 & 0.0 & 0.3 & 3.9 & 0.5 & 84.2 & 0.2 \\
Picea spp. & 0.0 & 0.5 & 3.4 & 4.5 & 1.3 & 5.9 & 65.8 & 9.3 & 3.5 & 1.6 \\
Pinus spp. & 0.8 & 1.0 & 77.7 & 2.9 & 8.2 & 4.7 & 5.0 & 4.6 & 0.5 & 2.2 \\
Thuja occidentalis & 0.0 & 1.7 & 2.4 & 77.3 & 4.0 & 1.3 & 3.9 & 2.7 & 4.8 & 3.7 \\
Tsuga canadensis & 4.1 & 2.4 & 4.3 & 2.6 & 70.3 & 2.5 & 0.3 & 0.5 & 0.0 & 1.2 \\
Other & 0.0 & 0.1 & 0.0 & 0.3 & 0.0 & 0.0 & 2.9 & 0.9 & 3.2 & 1.9 \\
\hline
\end{tabular}

Table A2. Relative abundance of taxa for groups $(n=9)$ from the current period, obtained by Ward's hierarchical clustering.

\begin{tabular}{cccccccccc}
\hline Present-Day Forest Type \# & $\mathbf{1}$ & $\mathbf{2}$ & $\mathbf{3}$ & $\mathbf{4}$ & $\mathbf{5}$ & $\mathbf{6}$ & $\mathbf{7}$ & $\mathbf{8}$ & $\mathbf{9}$ \\
\hline $\boldsymbol{n}$ & 1242 & 676 & 365 & 458 & 278 & 223 & 178 & 175 & 562 \\
Acer spp. & 69.3 & 9.0 & 1.8 & 6.8 & 15.7 & 5.9 & 2.3 & 13.4 & 11.3 \\
Betula alleghaniensis & 1.8 & 0.3 & 1.1 & 1.1 & 0.0 & 0.3 & 0.2 & 3.8 & 9.1 \\
Betula papyrifera & 1.7 & 3.0 & 1.5 & 3.0 & 1.3 & 1.8 & 2.8 & 2.3 & 11.5 \\
Fagus grandifolia & 3.9 & 0.5 & 0.0 & 0.0 & 1.1 & 0.2 & 0.0 & 3.3 & 11.7 \\
Fraxinus spp. & 1.4 & 0.8 & 4.0 & 1.5 & 0.5 & 0.3 & 1.0 & 0.5 & 13.3 \\
Ostrya virginiana & 2.5 & 0.3 & 0.1 & 0.4 & 4.0 & 0.7 & 0.7 & 0.4 & 6.9 \\
Populus spp. & 3.7 & 67.2 & 4.5 & 7.9 & 2.0 & 5.1 & 5.6 & 1.1 & 3.8 \\
Quercus spp. & 3.2 & 1.3 & 0.0 & 0.7 & 67.1 & 3.5 & 0.5 & 2.4 & 1.1 \\
Tilia americana & 3.9 & 1.0 & 0.6 & 1.1 & 1.0 & 0.3 & 0.3 & 0.6 & 10.1 \\
Ulmus spp. & 0.2 & 0.2 & 0.0 & 0.2 & 0.2 & 0.0 & 0.5 & 0.2 & 1.9 \\
Abies balsamea & 3.9 & 8.6 & 8.7 & 64.8 & 1.4 & 5.1 & 8.2 & 2.4 & 4.9 \\
Larix laricina & 0.0 & 0.0 & 0.5 & 0.2 & 0.0 & 0.1 & 0.3 & 0.0 & 0.9 \\
Picea spp. & 0.9 & 2.9 & 2.7 & 5.1 & 1.1 & 5.0 & 70.1 & 1.4 & 1.8 \\
Pinus spp. & 0.9 & 2.1 & 0.8 & 2.0 & 3.4 & 67.1 & 3.3 & 1.3 & 0.6 \\
Thuja occidentalis & 0.4 & 1.6 & 73.0 & 3.5 & 0.0 & 2.5 & 2.6 & 0.8 & 2.3 \\
Tsuga canadensis & 1.8 & 0.4 & 0.3 & 0.8 & 1.0 & 1.5 & 0.3 & 66.1 & 0.7 \\
Other & 0.5 & 0.8 & 0.4 & 0.8 & 0.1 & 0.5 & 1.2 & 0.1 & 7.9 \\
\hline
\end{tabular}

\section{References}

1. Fuller, J.L.; Foster, D.R.; McLachlan, J.S.; Drake, N. Impact of human activity on regional forest composition and dynamics in central New England. Ecosystems 1998, 1, 76-95. [CrossRef]

2. Thompson, J.R.; Carpenter, D.N.; Cogbill, C.V.; Foster, D.R. Four centuries of change in northeastern United States forests. PLoS ONE 2013, 8, e72540. [CrossRef] [PubMed]

3. Nowacki, G.J.; Abrams, M.D. Is climate an important driver of post-European vegetation change in the Eastern United States? Glob. Chang. Biol. 2015, 21, 314-334. [CrossRef] [PubMed]

4. Simard, H.; Bouchard, A. The precolonial 19th century forest of the Upper St. Lawrence Region of Quebec: A record of its exploitation and transformation through notary deeds of wood sales. Can. J. For. Res. 1996, 26, 1670-1676. [CrossRef]

5. Thompson, I.D.; Simard, J.H.; Titman, R.D. Historical changes in white pine (Pinus strobus L.) density in Algonquin Park, Ontario, during the 19th century. Nat. Area J. 2006, 26, 61-71. [CrossRef]

6. Marchand, N.; Filion, L. A dendroecological analysis of eastern hemlock and white pine in relation to logging in La Mauricie National Park (Québec, Canada). For. Chron. 2014, 90, 351-360. [CrossRef]

7. Dupuis, S.; Arseneault, D.; Sirois, L. Change from pre-settlement to present-day forest composition reconstructed from early land survey records in eastern Québec, Canada. J. Veg. Sci. 2011, 22, 564-575. [CrossRef]

8. Danneyrolles, V.; Arseneault, D.; Bergeron, Y. Pre-industrial landscape composition patterns and post-industrial changes at the temperate-boreal forest interface in western Quebec, Canada. J. Veg. Sci. 2016, 27, 470-481. [CrossRef] 
9. Gauthier, S.; Vaillancourt, M.-A.; Kneeshaw, D.D.; Drapeau, P.; de Grandpré, L.; Claveau, Y.; Paré, D. Forest ecosystem management: Origins and foundations. In Ecosystem Management in the Boreal Forest; Gauthier, S., Vaillancourt, M.-A., Leduc, A., de Grandpré, L., Kneeshaw, D.D., Morin, H., Drapeau, P., Bergeron, Y., Eds.; Les Presses de l'Université du Québec: Quebec, QC, Canada, 2009; pp. 13-38.

10. Boucher, Y.; Bouchard, M.; Grondin, P.; Tardif, P. Le Registre des états de Référence: Intégration des Connaissances sur la Structure, la Composition et la Dynamique des Paysages Forestiers Naturels du Québec Méridional; Gouvernement du Québec, Direction de la Recherche Forestière: Quebec, QC, Canada, 2011; pp. 1-14.

11. Whitney, G.G. From Coastal Wilderness to Fruited Plain. A History of Environmental Change in Temperate North America from 1500 to the Present; Cambridge University Press: Cambridge, UK, 1994; pp. 1-38.

12. Foster, D.R.; Motzkin, G.; Slater, B. Land-use history as long-term broad-scale disturbance: Regional forest dynamics in central New England. Ecosystems 1998, 1, 96-119. [CrossRef]

13. Radeloff, V.C.; Mladenoff, D.J.; He, H.S.; Boyce, M.S. Forest landscape change in the northwestern Wisconsin Pine Barrens from pre-European settlement to the present. Can. J. For. Res. 1999, 29, 1649-1659. [CrossRef]

14. Rhemtulla, J.M.; Mladenoff, D.J.; Clayton, M.K. Legacies of historical land use on regional forest composition and structure in Wisconsin, USA (mid-1800s-1930s-2000s). Ecol. Appl. 2009, 19, 1061-1078. [CrossRef] [PubMed]

15. Siccama, T.G. Presettlement and present forest vegetation in northern Vermont with special reference to Chittenden County. Am. Midl. Nat. 1971, 85, 153-172. [CrossRef]

16. Whitney, G.G. An ecological history of the great lakes forest of Michigan. J. Ecol. 1987, 75, 667-684. [CrossRef]

17. Abrams, M.D.; Ruffner, C.M. Physiographic analysis of witness-tree distribution (1765-1798) and present forest cover through north central Pennsylvania. Can. J. For. Res. 1995, 25, 659-668. [CrossRef]

18. Zhang, Q.; Pregitzer, K.S.; Reed, D.D. Historical changes in the forests of the Luce District of the Upper Peninsula of Michigan. Am. Midl. Nat. 2000, 143, 94-110. [CrossRef]

19. Leahy, M.J.; Pregitzer, K.S. A comparaison of presettlement and present-day forests in northeastern Lower Michigan. Am. Midl. Nat. 2003, 149, 71-89. [CrossRef]

20. Vadeboncoeur, M.A.; Hamburg, S.P.; Cogbill, C.V.; Sugimura, W.Y. A comparison of presettlement and modern forest composition along an elevation gradient in central New Hampshire. Can. J. For. Res. 2012, 42, 190-202. [CrossRef]

21. Leadbitter, P.; Euler, D.; Naylor, B. A comparison of historical and current forest cover in selected areas of the Great Lakes-St. Lawrence forest of central Ontario. For. Chron. 2002, 78, 522-529. [CrossRef]

22. Brisson, J.; Bouchard, A. In the past two centuries, human activities have caused major changes in the tree species composition of southern Québec, Canada. Ecoscience 2003, 10, 235-246.

23. Aubé, M. The pre-European settlement forest composition of the Miramichi River watershed, New Brunswick, as reconstructed using witness trees from original land surveys. Can. J. For. Res. 2008, 38, 1159-1183. [CrossRef]

24. Pinto, F.; Rornaniuk, S.; Ferguson, M. Changes to preindustrial forest tree composition in central and northeastern Ontario, Canada. Can. J. For. Res. 2008, 38, 1842-1854. [CrossRef]

25. Zelazny, V.F.; Veen, H.; Colpitts, M.C. Potential Forests of the Fundy Model Forest; New Brunswick Department of Natural Resources and Energy, Forest Management Branch: Fredericton, NB, Canada, 1997.

26. Saucier, J.-P.; Robitaille, A.; Grondin, P. Cadre bioclimatique du Québec. In Manuel de Foresterie: Écologie Forestière, 2nd ed.; Saucier, J.-P., Grondin, P., Robitaille, A., Gosselin, J., Morneau, C., Richard, P.J.H., Brisson, J., Sirois, L., Leduc, A., Morin, H., et al., Eds.; Éditions MultiMondes: Quebec, QC, Canada, 2009; pp. 186-206.

27. Grondin, P.; Gauthier, S.; Borcard, D.; Bergeron, Y.; Noël, J. A new approach to ecological land classification for the Canadian boreal forest that integrates disturbances. Landsc. Ecol. 2014, 29, 1-16. [CrossRef]

28. Ferree, C.; Anderson, M.G. A Map of Terrestrial Habitats of the Northeastern United States: Methods and Approach; The Nature Conservancy, Eastern Conservation Science, Eastern Regional Office: Boston, MA, USA, 2013; pp. 1-45.

29. Hobbs, R.J.; Arico, S.; Aronson, J.; Baron, J.S.; Bridgewater, P.; Cramer, V.A.; Epstein, P.R.; Ewel, J.J.; Klink, C.A.; Lugo, A.E.; et al. Novel ecosystems: Theoretical and management aspects of the new ecological world order. Glob. Ecol. Biogeogr. 2006, 15, 1-7. [CrossRef]

30. Hobbs, R.J.; Higgs, E.; Hall, C.M.; Bridgewater, P.; Chapin, F.S.; Ellis, E.C.; Ewel, J.J.; Hallett, L.M.; Harris, J.; Hulvey, K.B.; et al. Managing the whole landscape: Historical, hybrid, and novel ecosystems. Front. Ecol. Environ. 2014, 12, 557-564. [CrossRef] 
31. Jackson, S.T.; Hobbs, R.J. Ecological restoration in the light of ecological history. Science 2009, 325, 567-569. [CrossRef] [PubMed]

32. Gosselin, J.; Doyon, F. Description des domaines bioclimatiques: Domaine de l'érablière à tilleul. In Manuel de Foresterie: Écologie Forestière, 2nd ed.; Saucier, J.-P., Grondin, P., Robitaille, A., Gosselin, J., Morneau, C., Richard, P.J.H., Brisson, J., Sirois, L., Leduc, A., Morin, H., et al., Eds.; Éditions MultiMondes: Quebec, QC, Canada, 2009; pp. 215-227.

33. Dyke, A.S. An outline of North American deglaciation with emphasis on central and northern Canada. In Quaternary Glaciations-Extent and Chronology_Part II: North America; Ehlers, J., Gibbard, P.L., Eds.; Elsevier: Amsterdam, The Netherlands, 2004; pp. 373-424.

34. Brandt, J.P. The extent of the North American boreal zone. Environ. Rev. 2009, 17, 101-161. [CrossRef]

35. Gosselin, J. Guide de Reconnaissance des Types Écologiques: Région Écologique 2a, Collines de la Basse Gatineau; Gouvernement du Québec, Direction des Inventaires Forestiers: Quebec, QC, Canada, 2004; pp. 48-53.

36. Greffe de l'Arpenteur Général du Québec. Available online: https://appli.mern.gouv.qc.ca/Gagq (accessed on 22 August 2016).

37. Fournier, R. Plantes Vasculaires du Nouveau-Brunswick: Dicotylédones-Synonymes; Université de Moncton, Campus d'Edmundston, Faculté de foresterie: Edmunston, NB, Canada, 2006; pp. 2-141.

38. Fournier, R. Plantes Vasculaires du Nouveau-Brunswick: Ptéridophytes et Gymnospermes-Synonymes; Université de Moncton, Campus d'Edmundston, Faculté de foresterie: Edmunston, NB, Canada, 2006; pp. 2-97.

39. Jackson, S.M.; Pinto, F.; Malcolm, J.R.; Wilson, E.R. A comparison of pre-European settlement (1857) and current (1981-1995) forest composition in central Ontario. Can. J. For. Res. 2000, 30, 605-612. [CrossRef]

40. Seischab, F.K. Presettlement forests of the Phelps and Gorham purchase in Western New York. Bull. Torrey Bot. Club 1990, 117, 27-38. [CrossRef]

41. Scull, P.R.; Richardson, J.L. A method to use ranked timber observations to perform forest composition reconstruction from land survey data. Am. Midl. Nat. 2007, 158, 446-460. [CrossRef]

42. Terrail, R.; Arseneault, D.; Fortin, M.-J.; Dupuis, S.; Boucher, Y. An early forest inventory indicates high accuracy of forest composition data in pre-settlement land survey records. J. Veg. Sci. 2014, 25, 691-702. [CrossRef]

43. Frontier, S. Decrease of eigenvalues in principal component analysis-Comparison with broken stick model. J. Exp. Mar. Biol. Ecol. 1976, 25, 67-75. [CrossRef]

44. Les Placettes-Échantillons Temporaires. Available online: https://www.mffp.gouv.qc.ca/forets/inventaire/ inventaire-placettes.jsp (accessed on 10 October 2016).

45. Oksanen, J.; Blanchet, G.; Kindt, R.; Legendre, P.; Minchin, P.R.; O’Hara, R.B.; Simpson, G.L.; Solymos, P.; Stevens, M.H.H.; Wagner, H. vegan: Community Ecology Package. R Package Version 1.17-4. 2010. Available online: https:/ /CRAN.R-project.org/package=vegan (accessed on 19 August 2016).

46. R Core Team. R: A Language and Environment for Statistical Computing; R Foundation for Statistical Computing: Vienna, Austria, 2010.

47. Ward, J.H. Hierarchical grouping to optimize an objective function. J. Am. Stat. Assoc. 1963, 58, $236-244$. [CrossRef]

48. Wang, Y.-C. Spatial patterns and vegetation-site relationships of the presettlement forests in western New York, USA. J. Biogeogr. 2007, 34, 500-513. [CrossRef]

49. Palik, B.J.; Pregitzer, K.S. A comparison of presettlement and present-day forests on two bigtooth aspen-dominated landscapes in northern Lower Michigan. Am. Midl. Nat. 1992, 127, 327-338. [CrossRef]

50. Cowell, C.M. Historical change in vegetation and disturbance on the Georgia piedmont. Am. Mild. Nat. 1998, 140, 78-89. [CrossRef]

51. Friedman, S.K.; Reich, P.B. Regional legacies of logging: Departure from presettlement forest conditions in northern Minnesota. Ecol. Appl. 2005, 15, 726-744. [CrossRef]

52. Mauri Ortuno, E. Modélisation de la Distribution Précoloniale du Pin Blanc en Moyenne-Mauricie à partir des Carnets d'Arpentage. Master's Thesis, Université Laval, Quebec, QC, Canada, 2010.

53. Mauri Ortuno, E.; Doyon, F. Estimation de la Distribution des Essences Forestières au 19e Siècle dans l'Outaouais à l'aide des Carnets d'Arpentage des Limites des Concessions Forestières; Institut Québécois d'Aménagement de la Forêt Feuillue (IQAFF): Ripon, QC, Canada, 2010. 
54. Sands, B.A.; Abrams, M.D. A 183-year history of fire and recent fire suppression impacts in select pine and oak forest stands of the Menominee Indian Reservation, Wisconsin. Am. Midl. Nat. 2011, 166, 325-338. [CrossRef]

55. Wendel, G.W.; Smith, H.C. Eastern white pine. In Silvics of North America-Volume 1: Conifers; Forest Service Agriculture Handbook; Burns, R.M., Honkala, B.H., Eds.; United States Department of Agriculture: Washington, DC, USA, 1990; pp. 972-999.

56. Fahey, T.J.; Reiners, W.A. Fire in the forests of Maine and New Hampshire. Bull. Torrey Bot. Club 1981, 108, 362-373. [CrossRef]

57. Doyon, F.; Bouffard, D. Enjeux Écologiques de la Forêt Feuillue Tempérée Québécoise; Institut Québécois d'Aménagement de la Forêt Feuillue (IQAFF): Ripon, QC, Canada, 2009.

58. Raymond, P.; Munson, A.D.; Ruel, J.C.; Nolet, P. Group and single-tree selection cutting in mixed tolerant hardwood-white pine stands: Early establishment dynamics of white pine and associated species. For. Chron. 2003, 79, 1093-1106. [CrossRef]

59. Quenneville, R.; Thériault, M. La restauration des écosystèmes de pin blanc (Pinus strobus): Un enjeu majeur pour le parc national de la Mauricie. Nat. Can. 2001, 125, 39-42.

60. White, M.A.; Mladenoff, D.J. Old-growth forest landscape transitions from pre-European settlement to present. Landsc. Ecol. 1994, 9, 191-205. [CrossRef]

61. Suffling, R.; Evans, M.; Perera, A. Presettlement forest in southern Ontario: Ecosystems measured through a cultural prism. For. Chron. 2003, 79, 485-501. [CrossRef]

62. Mladenoff, D.J.; Stearns, F. Eastern hemlock regeneration and deer browsing in the Great Lakes region: A re-examination and model simulation. Conserv. Biol. 1993, 7, 889-900. [CrossRef]

63. Payette, S.; Pilon, V.; Couillard, P.-L.; Frégeau, M. Holocene dynamics of an eastern hemlock (Tsuga canadensis) forest site at the northern range of the species limit. Holocene 2015, 25, 1246-1256. [CrossRef]

64. Brisson, J.; Bergeron, Y.; Bouchard, A. Les successions secondaires sur sites mésiques dans le Haut-SaintLaurent, Québec, Canada. Can. J. Bot. 1988, 66, 1192-1203. [CrossRef]

65. Réserve Écologique de la Forêt-la-Blanche. Available online: http://www.mddelcc.gouv.qc.ca/biodiversite/ reserves/foret_lablanche/res_69.htm (accessed on 19 August 2016).

66. Nolet, P.; Delagrange, S.; Bouffard, D.; Doyon, F.; Forget, E. The successional status of sugar maple (Acer saccharum), revisited. Ann. For. Sci. 2008, 65, 208. [CrossRef]

67. Doyon, F.; Bouchard, A.; Gagnon, D. Tree productivity and successional status in Quebec northern hardwoods. Ecoscience 1998, 5, 222-231.

68. Angers, V.A.; Messier, C.; Beaudet, M.; Leduc, A. Comparing composition and structure in old-growth and harvested northern hardwood stands in Quebec. For. Ecol. Manag. 2005, 217, 275-293. [CrossRef]

69. Doyon, F.; Bouffard, D. Étude sur le Bois Mort, les Microsites et la Régénération après Chablis Catastrophiques dans les Érablières du Témiscamingue; Institut Québécois d'Aménagement de la Forêt Feuillue (IQAFF): Ripon, QC, Canada, 2008.

70. Cogbill, C.V. Historical biogeography of American beech. In Beech Bark Disease, Proceedings of the Beech Bark Disease Symposium, Saranac Lake, NY, USA, 16-18 June 2004; USDA Forest Service: Newtown, PA, USA, 2005; pp. 16-24.

71. Grandtner, M. La Végétation Forestière du Québec Méridional; Les Presses de l’Université Laval: Quebec, QC, Canada, 1966.

72. Beaudet, M.; Messier, C. Growth and morphological responses of yellow birch, sugar maple, and beech seedlings growing under a natural light gradient. Can. J. For. Res. 1998, 28, 1007-1015. [CrossRef]

73. Drinkwater, M.H. Field Spruce in Nova Scotia; Government of Canada, Department of Northern Affairs and National Resources, Forestry Branch: Ottawa, ON, Canada, 1957.

74. Wang, Y.-C.; Kronenfeld, B.J.; Larsen, C.P.S. Spatial distribution of forest landscape change in western New York from presettlement to the present. Can. J. For. Res. 2009, 39, 76-88. [CrossRef]

75. Abrams, M.D. Fire and the development of oak forests. BioScience 1992, 42, 346-353. [CrossRef]

76. Terrail, R. Influence de la Colonisation sur les Transformations du Paysage Forestier depuis l'Époque Préindustrielle dans l'est du Québec (Canada). Ph.D. Thesis, Université du Québec à Rimouski, Rimouski, QC, Canada, 2013.

77. Drever, C.R.; Messier, C.; Bergeron, Y.; Doyon, F. Fire and canopy species composition in the Great Lakes-St. Lawrence forest of Témiscamingue, Québec. For. Ecol. Manag. 2006, 231, 27-37. [CrossRef] 
78. Dey, D.C.; Guyette, R.P. Anthropogenic fire history and red oak forests in south-central Ontario. For. Chron. 2000, 76, 339-347. [CrossRef]

79. Perala, D.A. Quaking aspen. In Silvics of North America-Volume 2: Hardwoods; Forest Service Agriculture Handbook; Burns, R.M., Honkala, B.H., Eds.; United States Department of Agriculture: Washington, DC, USA, 1990; pp. 1082-1115.

80. Boucher, Y.; Grondin, P.; Auger, I. Land use history (1840-2005) and physiography as determinants of southern boreal forests. Landsc. Ecol. 2014, 29, 437-450. [CrossRef]

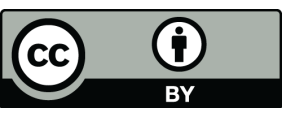

(C) 2016 by the authors; licensee MDPI, Basel, Switzerland. This article is an open access article distributed under the terms and conditions of the Creative Commons Attribution (CC-BY) license (http://creativecommons.org/licenses/by/4.0/). 